\title{
CULLEN, BROWN AND THE POVERTY OF ESSENTIALISM
}

\author{
by
}

\section{CHRISTOPHER LAWRENCE*}

In 1795 the Bristol physician, Thomas Beddoes, introduced his edition of John Brown's The elements of medicine with the remark "It was not unusual for Brown's disciples to disagree, when they were called upon for a strict interpretation of his principal tenets." Over a hundred years later, the London doctor Benjamin Ward Richardson made a similar observation: "Each of the different commentators of the Brunonian hypothesis has given an interpretation according to his own reading of it."2 In spite of the difficulties which they had identified, both Beddoes and Richardson elucidated what they understood to be the essence of Brunonianism, the medical system identified with the eighteenth-century Scottish physician, John Brown. The discovery of a variety of meanings in Brown's writings, which both Beddoes and Richardson pointed to, is not a phenomenon confined to the system itself. Brown's various biographers have also come to varying conclusions about the meanings of his behaviour and utterances during his life. ${ }^{3}$

Two of the most important sources for the life of Brown are the accounts by Thomas Beddoes, and that by Brown's son, William Cullen Brown. Beddoes's life appeared in 1795, prefixed to his edition of Brown's Elements. Beddoes stated that his life of Brown, or Bruno as he was sometimes called, was based on obituary notices and "communications" with Mr Wait, "late respectable rector of Dumfries School". $\mathrm{He}$ admitted to shortcomings in his biography, because "very little of the information I had reason to expect, has reached me."4 Beddoes edited the works of Bruno ("my hero" as he called him) in order, he said, to procure assistance for Brown's impoverished family. In addition, he hoped that the new edition with "observations on the character and writings of John Brown" would be a "consolation to [other] men of genius, pining under poverty and neglect". ${ }^{5}$ Hardly, it might seem, the basis for a hostile account. However, William Cullen Brown, in his

\footnotetext{
* Christopher Lawrence, MB, ChB, MSc, PhD, Wellcome Institute for the History of Medicine, 183 Euston Road, London NW1 2BP.

${ }^{1}$ John Brown, The elements of medicine. A new edition, revised and corrected with a biographical preface by Thomas Beddoes M.D., London, J. Johnson, 1795, vol. 1, p. cxxxvii.

2 Benjamin Ward Richardson, Disciples of Aesculapius, London, Hutchinson \& Co., 1900, vol. 1, p. 253.

${ }^{3}$ I shall not deal here with very recent interpretations of Brown's life and teaching. Instead, I shall attempt to contextualize the interpretations of the biographers for whom Brunonianism was a medical movement with which it was necessary to engage intellectually, because it either posed a threat or was seen as an important advance.

Brown, op. cit., note 1 above, pp. xxxvi-xxxvii.

5 Ibid., pp. viii, xxxv-xxxvi.
} 


\section{Christopher Lawrence}

life of his father which appeared nine years later in 1804, accused Beddoes of using "scanty material" and of stigmatizing his father in the following manner:

... his want of medical erudition confidently affirmed; his composition, both in Latin and English, vilified; the extent of his practice questioned; he is arraigned of bigotry and pedantry in his youth, and of irreligion and arrogance in advanced life ... his person . . . is likened to that of the clumsy buffoon in Cervantes...6.

John Brown was born either in 1735 or 36 in the parish of Buncle in the county of Berwick in Scotland. ${ }^{7}$ He was, according to his son, a child prodigy and, by the age of five, had read the whole of the Old Testament. ${ }^{8}$ Of Brown's childhood the ostensibly hostile Beddoes observed, "I conclude that he was endowed with that quickness of sympathy and that sensibility to the charms of nature, which characterize the infancy of genius."9 After attending the local school Brown was apprenticed to a weaver. He soon left this employment, however, and went to the nearby grammar school because, as his son put it, to one so "highly cultivated; it may be readily conceived how truly disgusting the sordid life of one of the lowest mechanical businesses must have proved."10 Brown's biographers credit him with a reputation for great physical and mental strength in his grammar school years. Beddoes stated that he "had vigour of body with vigour of mind, and exerted both". 11 At some point in his youth he renounced the faith of the strict religious sect to which his family belonged. Beddoes recorded this with some relief since, as he put it, "I see not what should have hindered a man endowed with so acute and comprehensive a genius from attaining equal pre-eminence in polemical divinity."12

By 1755 Brown's reputation as a scholar gained him the position of tutor in a laird's household. Scarcely had he entered this post, however, than he left. In Beddoes's opinion Brown "did not long continue to be an agreeable inmate [because it] is likely enough that he added the stiffness of pedantry to the sourness of bigotry." ${ }^{13}$ His son, on the other hand, concluded that Brown had left because "he was not treated with the respect due to his situation." 14 From here Brown went to Edinburgh to study divinity. He soon gave this up too, however, and turned his attention to medicine. For this period of Brown's life a third biographical source, John Thomson's Life of William Cullen, offers yet another interpretation of Brown's career. Thomson's work, written in the 1820s, had a perspective quite different from that of Beddoes or Brown's son, as Thomson made plain:

\footnotetext{
${ }^{6}$ John Brown, The works of Dr John Brown M.D. To which is prefixed a biographical account of the author, by $W$. C. Brown, 3 vols., London, J. Johnson, 1804, vol. 1, pp. v-vii.

${ }_{7}$ Brown's early biographers (including his son) give conflicting accounts of the date and village (variously Lintlaws or Preston) of his birth. His most recent serious student is definite about 1736 and Preston, but cites no other sources than the first accounts. See Guenter B. Risse, 'The history of John Brown's medical system in Germany during the years 1790-1806, Ph.D diss., University of Chicago, 1971, p. 69.

${ }^{8}$ Brown, op. cit., note 6 above, p. xix.

${ }^{9}$ Brown, op. cit., note 1 above, p. xxxvii.

${ }^{10}$ Brown, op. cit., note 6 above, p. xxvi.

11 Brown, op. cit., note 1 above, p. xli.

12 Ibid., p. xliv.

13 Ibid., p. xlv.

14 Brown, op. cit., note 6 above, p. xli.
} 


\section{Cullen, Brown and the poverty of essentialism}

It is in the first place to be observed, that the two biographical accounts of Dr Brown given by Dr Beddoes and by William Cullen Brown, the son of Dr Brown, contain so many erroneous statements, so many representations quite at variance with facts, that they may, without injustice, be pronounced to be rather agreeable romances, and extraordinary pieces of fiction, than genuine narratives of matters of fact. ${ }^{15}$

In spite of their differences, all three authors agree that during his first four or five years studying medicine at Edinburgh, Brown was admitted free by the professors to their lectures, that he taught Latin, and that he became a grinder or extramural coach and composer of theses. In 1765 Brown opened a boarding house. At this time, according to his son,

The pleasures of the table and the unconstrained hilarity he enjoyed at the convivial meetings of . . . [his] . . . companions, were by nature sufficiently agreeable to one of his vivacity of disposition and strong passions. ${ }^{16}$

Beddoes saw matters rather differently and suggested that Brown "seems to have given in to the most dangerous of vices". ${ }^{17}$ Also during these years, his son relates, Brown, in consequence of his menial position, had to render himself "agreeable to those on whom his livelihood depended". ${ }^{18}$ One of these was the popular and well-connected professor of medicine, William Cullen. Brown's son represented Cullen as the exploiter of his father's talents. He wrote that "Dr Cullen, who was extremely deficient in classical erudition, conceived the idea of turning his pupil's intimate knowledge of Latin to his own permanent advantage." 19 Beddoes took a similar view. John Thomson, however, had a rather different perception of the relationship:

It is stated, more or less distinctly, both by Dr Beddoes and by Dr C. Brown, that Dr Cullen found Mr John Brown's knowledge of the Latin language useful, and made him a sort of amanuensis or Latin secretary. This is entirely a piece of invention. The only capacity in which Dr Cullen employed Mr John Brown was as tutor or private teacher to his children, to assist them in the preparation of their lessons and their Latin exercises. ${ }^{20}$

Thomson further professed incomprehension that Beddoes could possibly think that a man as great as Cullen would employ, as an amanuensis, a man who was little more than an adept at the art of "low buffoonery". 21

The events following Brown's association with Cullen are the subject of striking differences of interpretation among the biographers. According to Brown's son and Beddoes, Cullen had promised to exert his interest on Bruno's behalf for the first

\footnotetext{
15 John Thomson, An account of the life, lectures and writings of William Cullen M.D., Edinburgh, William Blackwood and Sons, 1859, vol. 2, p. 710. This work was actually completed by Thomson's son William and by David Craigie, but for the purposes of the present paper the book can be considered a single-authored text, since these other two authors completed the book by using Thomson's manuscripts.

${ }_{16}$ Brown, op. cit., note 6 above, p. lii.

17 Brown, op. cit., note 1 above, p. li.

18 Brown, op. cit., note 6 above, p. liii.

19 Ibid., p. lv.

20 Thomson, op. cit., note 15 above, vol. 2, p. 711. Thomson defended Cullen's knowledge of Latin. Interestingly, it had been called into question before, at the time of Cullen's bid for the chair of the Practice of Physic. See [Anon], A letter from a citizen of Edinburgh to Doctor Puff, Edinburgh, 1764, p. 11.

21 Thomson, op. cit., note 15 above, p. 713.
} 
vacant University chair and, accordingly, in 1776 Brown put himself forward for the chair of the Institutes of Medicine. ${ }^{22}$ Beddoes contended that Cullen, on being shown the name of Brown in the list of candidates, is said to have exclaimed in the "vulgar dialect" of the country "Why sure this can never be our Jock?"23 Beddoes was here suggesting that the urbane Cullen was stigmatizing Brown as a rustic and thus wholly inappropriate to aspire to an Edinburgh Chair and the polite social world to which it gave entry. Thomson, however, denied the suggestion that Cullen had ever encouraged Brown and, indeed, claimed that the Town Council records showed that Brown had never been a candidate for the chair. ${ }^{24}$ Following this episode there was at least one further serious disagreement between Cullen and Brown. Brown put his name forward for election to the prestigious Edinburgh Philosophical Society and was duly blackballed. According to Thomson, Cullen had advised Brown, for his own good, "to withdraw his application". ${ }^{25}$ Brown's son, however, held that his father's rejection was negotiated by Cullen, jealous of his own originality and "dreading the shock, which his own favourite opinions ... would sustain ... from a rival". ${ }^{26}$ The result, Beddoes stated, was that "Cullen estranged the mind of his Latin secretary" or, as Thomson observed, "Cullen ceased to hold any communication with him; it is said even to mention his name." 27 Following the breach between the two men, Brown began to teach his own system of medicine in Edinburgh in opposition to that of Cullen, and in 1780 he published the Elementa medicinae and, anonymously in 1787, Observations on the principles of the old system of physic. Another Brunonian work, An inquiry into the state of medicine, was published in 1781 under the name of Robert Jones, although Brown's son stated that the work was written by his father since it was a "moral certainty" that it could not have been the production of Jones. ${ }^{28}$

Brunonianism certainly caused a stir. Its adherents created havoc with the intellectual life of Edinburgh, especially in the 1780s in the students' Royal Medical Society and in the Royal Infirmary. ${ }^{29}$ There can be no doubt either of the rancour which the controversy generated on both sides, nor the violence with which the dispute was pursued. Brown's son accused "Dr Cullen and his abettors" of being "ungenerous and disgraceful" and of attempting to "crush the doctrine, and involve its author and his family in ruin". ${ }^{30}$ Beddoes, a trifle less sympathetic, noted "as the Cullenian hypotheses were sinking into disrepute, many of the ablest students resorted to the standard of Brown, ... it was joined also by the most idle and dissolute." 11

The remainder of Brown's life in Edinburgh was as colourful as his early career. In 1784 or 1785, he established a Masonic institution, 'The Lodge of the Roman Eagle', with the noble intention, said his son, of preventing the decline of Roman language and

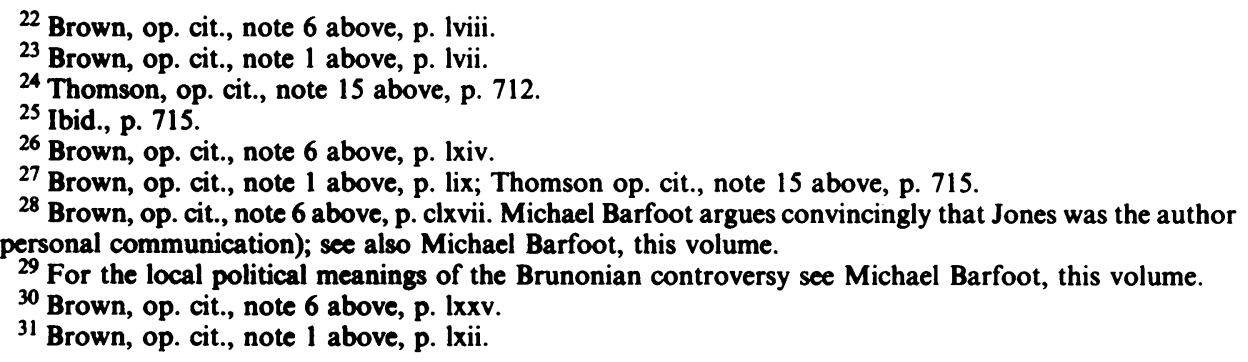




\section{Cullen, Brown and the poverty of essentialism}

literature. 32 Beddoes less generously suggested that Brown saw that the medical students' interest in Freemasonry "afforded him a chance of proselytes". ${ }^{33}$ In 1786, according to Thomson, Brown, in "straitened circumstances, and in debt" moved to London, where he died, after a spell of imprisonment, in 1788, aged about fifty-two. ${ }^{34}$ Beddoes recorded that "he died, if I am not misinformed, in the night, having swallowed as he went to bed a very large dose of laudanum; a species of dram to which he had indeed been long addicted." 35

All these authors, including the hostile Thomson, developed the view that Brown's character, or perhaps rightly, his charisma, was the foundation of the attraction of his teachings, both to students and others. They also concur in the opinion that this charisma was fuelled by the consumption of large amounts of brandy and opium. The charisma, however, was not universally effective. Beddoes recorded that, after encountering Brown in 1782 "I never desired his conversation a second time." $\mathrm{He}$ spoke, said Beddoes, with a "Doric dialect" which "had nothing prepossessing to an English ear. It was so broad as to leave me often uncertain of what he said." 36 Beddoes also gave an equally unsympathetic account of a Brunonian evening:

One of his pupils informs me that when he found himself languid, he sometimes placed a bottle of whisky in one hand, and a phial of laudanum on the other; and that, before he began his lecture, he would take forty or fifty drops of laudanum in a glass of whisky; repeating the dose four or five times during the lecture. Between the effects of these stimulants and voluntary exertion, he soon waxed warm, and by degrees his imagination was exalted into phrenzy. ${ }^{37}$

His son, however, denied the charges of gross indulgence and claimed that his father's "intemperate excesses" were "egregiously exaggerated", and that "many ridiculous stories of the frolics committed by him in a state of ebriety have been circulated at his expense." 38 But Bruno, as even his son admitted, "was rather free in his religious sentiments" and also had unconventional political allegiances. ${ }^{39}$ Beddoes recorded that "Brown was the first person I ever saw absurd enough to profess himself a Jacobite." ${ }^{, 0}$ His son, however, rendered this undeniable association honourable by claiming that no one should be surprised that "a cause which has induced the most honourable and bravest chieftains in Scotland disinterestedly to draw their swords should have been espoused by a man of his warmth."41

Although they agreed on many details, these earliest biographers of Brown differed considerably in their interpretations of his actions. This is hardly surprising since they wrote from quite different social and personal perspectives. In the instance of Brown's son, the defence of his father's behaviour would seem to lie in the filial relationship. In the case of Thomson and Beddoes, their differing accounts seem to be

32 Brown, op. cit., note 6 above, p. Ixxix.

33 Brown, op. cit., note 1 above, p. Ixxxv.

34 Thomson, op. cit., note 15 above, p. 716.

35 Brown, op. cit., note 1 above, p. xciii.

36 Ibid., p. Ixxx.

37 Ibid., p. Ixxxvii.

38 Brown, op. cit., note 6 above, p. cxxxiii.

39 Ibid., p. cxxxviii.

${ }^{40}$ Brown, op. cit., note 1 above, p. lxxxi. For the local meanings of this association see Barfoot, this volume.

${ }^{41}$ Brown, op. cit., note 6 above, p. cxli. 


\section{Christopher Lawrence}

related to their diametrically opposed political positions. However, not only were their accounts of Brown's life at variance, so were their interpretations of his system as well as that of Cullen. These differences also derived from their political philosophies. Before Beddoes and Thomson engaged with Brunonianism, however, there had been other accounts of the system.

In an account published one year after the Elementa medicinae of 1780 , Brown himself, or more likely his close friend Robert Jones, described the core or crucial achievement of the system. This Jones represented as the first, correct application of the method of natural philosophy to medicine. A fundamental feature of this method was described by the Newtonian axiom that causes should not be multiplied and, Jones noted, "The application of this invaluable precept to medicine was discovered by Dr Brown." 42 By properly applying the method of induction Brown had been able to reduce "the whole phaenomena of life ... to one simple cause . . excitability" ${ }^{43}$ This he did by first observing the simplest of medical phenomena, health itself, and then ascending to examine disease, which exhibits "the most complex phaenomena, as referable to man". However, unlike other inquirers, at no point did Brown invoke new causes for these more complicated states. "This", said Jones of the system, was "a view of the animal-oeconomy equally new and scientific". ${ }^{44}$ In this text, therefore, Jones represented the essential feature of Brunonianism as being the recognition that the causes of health were the same as the causes of disease. Jones considered that Brown had achieved a feat comparable with that of Newton. He had arrived at "the most universal conception the mind can attain ... That is that all powers operating upon the animal and vegetable kingdoms, and creative of all their phaenomena, stimulate." ${ }^{45}$ From this, quite properly, followed the deduction that specific therapies were absurd. For since stimulation is the only power that can act on the body, what is actually curing the patient when a physician prescribes a so-called specific is simply stimulation, not some specific property of the drug. Thus Brown had recognized that the use of specifics was actually a variety of that most heinous of medical practices, empiricism. Giving a specific drug implied a specific disease, and to account for specific diseases physicians employed a "multiplicity of causes". Whereas in Brown's system "The cause he assigns is one . . a variation in the degree of excitement."46 Brown's philosophy, Jones continued, necessarily demonstrated that nosology was a false science, because it was based on the fundamental methodological error that diseases with similar symptoms have similar causes and diseases with dissimilar symptoms, dissimilar causes. Whereas, of course, there was only one cause of disease, a change in excitability.

The Inquiry was thus a text which represented the crucial or essential nature of Brunonianism to be its systematic character, resting on the correct application of a

\footnotetext{
42 Robert Jones, An inquiry into the state of medicine on the principles of inductive philosophy, Edinburgh, T. Longman and T. Cadell, London, C. Elliott, 1781, p. 86. For more details of Jones's life see Michael Barfoot, this volume. On its authorship see note 28 above: for present purposes authorship is unimportant, since both Brown and Jones were committed to challenging Edinburgh medicine on its own ground.

43 Jones, op. cit., note 42 above, p. 93.

44 Ibid., pp. 37-8.

45 Ibid., p. 71.

46 Ibid., pp. 85-7. Brown is attacking here the categories of predisposing, accessory, and proximate causes.
} 


\section{Cullen, Brown and the poverty of essentialism}

number of philosophical principles attributed to Newton. Effectively all the details of the system are deducible from these principles. Now systematic medicine was the basis of professional teaching in Edinburgh and knowledge of a system based on philosophical principles, identified with Newton, was taught by all the professors to be the hallmark of the rational or dogmatic physician. ${ }^{47}$ In keeping with this, the professors also taught that empiricism was the most contemptible of medical philosophies. Brown was educated within this tradition and, amongst other things, his attempts to obtain an Edinburgh MD suggest that he identified with it. ${ }^{48}$ It is also known, from both friendly and hostile sources, that Brown devised his system of medicine in opposition to that of Cullen, and that Brown taught his new system to the students. In this text, therefore, however apparently antagonistic to orthodox medicine it might seem, Jones, also medically educated in Edinburgh, was representing his friend's approach to medicine as falling squarely within the orthodox Scottish tradition. Indeed Jones argued, rather cleverly, that Brown's philosophy showed that previous Scottish systems were upholding the very philosophy they were designed to resist: empiricism. Thus Jones represented Brown in exactly the way that Cullen represented himself, as a supporter of the view that progress in medicine was to be achieved by employing fundamental philosophical principles in order to arrive at a general explanation graced by causal simplicity. Causal simplicity, in one way or another, was stipulated by such Scottish literati as David Hume, Adam Smith, and James Hutton as the cornerstone of a comprehensive and satisfying scientific explanation. ${ }^{49}$ Thus Jones presented Brown's achievement as having properly practised medical theorizing as advocated by the great Scottish thinkers. In this text, Jones represented Brown not as a destroyer of the old medicine, but as a reformer who shared ground rules with Cullen and others about what medicine was and how it was to be improved. Indeed, he was representing Brown in much the same way that Cullen had portrayed his own relation to Boerhaave. The Inquiry was published in 1781, when Brown was still in Scotland and attempting to attract orthodox students away from the University and particularly from Cullen. Its representation of Brunonianism as a methodically-achieved dogmatic system based on Newtonian principles was, therefore, a locally-tuned intervention into the traditions of Edinburgh medicine.

Not everyone, however, saw its systematic nature to be the essential feature of Brunonianism. Indeed, one of the earliest published responses to Brown's work ignored altogether these pretensions to a systemic character. This attack was the anonymous Observations on the medical practice of Dr. Brown, which appeared in 1788. It was almost certainly written by a regular, English, provincial practitioner.$^{50}$ For this

\footnotetext{
${ }^{47}$ See Christopher Lawrence, 'Medicine as culture: Edinburgh and the Scottish Enlightenment', Ph.D. diss., University of London, 1984 and idem, 'Ornate physicians and learned artisans' in W.F. Bynum and Roy Porter (editors), William Hunter and the medical world of the eighteenth century, Cambridge University Press, 1985, pp. 153-76.

48 He eventually received his degree from St. Andrew's.

49 See Lawrence, op. cit., note 47 above. Also on Smith and Hume see J. R. R. Christie, 'The rise and fall of Scottish science' in Maurice Crosland (editor), The emergence of science in Western Europe, London, Macmillan Press, 1975, pp. 111-26. On Hutton see Roy Porter, The making of geology, Cambridge University Press, 1977.

${ }^{50}$ [John Leedes Hemingston], Observations on the medical practice of Dr. Brown, Ipswich, 1788. Hemingston is identified as the author in the British Library Catalogue. I have been unable to find any
} 
author, the crucial part of the Brunonian doctrine was not its use of philosophical principles, but what he perceived as its radical therapeutic recommendations: in particular, that stimulants should be employed in inflammatory fevers. The author of the Observations was, medically speaking, a self-confessed conservative. He valued tradition and orthodoxy on the grounds that they necessarily embodied hundreds of years of accumulated experience. Further, orthodox wisdom was not primarily embodied in institutions or in books but in what physicians actually did at the bedside. Anything other than the most limited therapeutic innovation was, therefore, bad medicine. Eclecticism, gradual change, and deference to authority were themselves the signs that medicine was on its slow but sure path to "further improvement". 51 Thus for him the essence of Brown's work was its injunction to break with traditional practice. It was this which identified Brunonianism as a doctrine of a "singular and extraordinary nature". The most "conspicuous" part of this heresy was the recommendation that large doses of laudanum should be employed in fevers. This was a doctrine, the author remarked, which "surely, cannot but strike almost every person as uncommon and immoderate".52 From this author's position, Brown's teaching represented "Credulity, fashion, the love of novelty, and a propensity to rush from one extreme to another". 53 Not surprisingly the author underwrote tradition by invoking authority, referring to the "learned and ingenious ... Dr. Percival"; "that part of Dr. Cullen's works where he has so very ingeniously and satisfactorily discussed this subject"; "that truly ingenious man, Mr. John Hunter"; "those diligent observers of nature, Hippocrates and Sydenham"; "the elegant Celsus"; the "illustrious names, Cullen, Duncan and Gregory"; "that very learned and sagacious ... Dr. George Fordyce", the "celebrated Sir John Pringle"; "the eminent Hoffmann" and, finally, "that celebrated professor, bright ornament of the medical profession, Dr. Cullen". ${ }^{54}$ All of these great figures, he noted, avoided stimulants in inflammatory fevers, therefore, he deduced, this must be proper practice. Such prescribing, he said, "observe[d] due bounds" and "avoid[ed] those extravagant sallies which are generally looked upon to be the principal and leading marks of all extremes". 55

The author thus identified himself with orthodoxy, and defined orthodoxy itself as traditional, unspectacular practice and cautious innovation. He argued that it was therapeutic innovation or, worse, therapeutic radicalism which brought the profession into disrepute. In the years around the turn of the century such activity was increasingly seen by regulars as the distinguishing sign of a populist, a flagrant self-advertiser, or even a quack. The Observations, therefore, did not represent Brown as an inside reformer, as the Inquiry had done, but as a dangerous outsider, a subverter of long-standing tradition. Such a response to Brunonianism might be expected from a provincial, English, surgeon-apothecary. At this time general practitioners were slowly

\footnotetext{
trace of this man. However, a Mr Leedes, a surgeon who practised in Hemingstone, Suffolk c.1790-1830, seems the most likely author: I am grateful to Dr D. van Zwanenberg for this information.

51 Ibid., p. 5.

52 Ibid., p. 7.

53 Ibid., p. 20. Hemingston was quoting from Thomas Percival, Essays medical and experimental, 2nd ed., London, J. Johnson, 1757, p. 352.

${ }^{54}$ Hemingston, op. cit., note 50 above, pp. 7, 11, 14, 18, 21, 22, 29, 34.

55 Ibid., p. 39.
} 


\section{Cullen, Brown and the poverty of essentialism}

creating their self-identity in the face of intense competition. To do this they used their shared education and their common practice as signs of their orthodoxy. Brunonianism, to this author, therefore represented the worst of possible threats, a regularly-trained doctor whose therapeutics seemingly made him indistinguishable from quacks. 56

Other authors also saw striking innovation as the kernel of Brown's teaching. But some, for instance Thomas Beddoes, represented Brown's break with tradition as a virtue. Beddoes was a political radical and, in 1795, a year in which he was involved in anti-government agitation, he published a defence of Bruno's works which represented them as revolutionary texts. ${ }^{57}$ Beddoes held that Brown's achievement was to have cut through the problem of the nature of life. Beddoes began, "Brown, avoiding all useless disquisition concerning the cause of vitality, confines himself to the phaenomena." 58 This was a significant reading. The similarity of Beddoes's description of Brown's work to the so-called materialistic doctrines of such French ideologues as Cabanis, with which Beddoes was very familar, is obvious. ${ }^{59}$ In France the analysis of the phenomena of life was central to the ideologues' establishment of physiology as the fundamental science of mind and society. To the ideologues, speculation on unknown and unknowable causes of life was pointless (Beddoes's "useless disquisition"). A further feature of ideology was its use of environmentalism as the intellectual foundation of a system of medical police. Not surprisingly Beddoes, social reformer and educationalist, argued that until Brown "No writer had insisted so much upon the dependence of life on external causes." 60

In his account of Brunonianism, Beddoes also addressed the suggestion that Brown's teaching had its origin in what Beddoes called the "obscure opinions of Dr Cullen". ${ }^{61}$ Beddoes, however, had no confidence in this view. He quoted a sentence from Cullen which, so he said, had been used by others to prove Brown's plagiarism.

\footnotetext{
${ }^{56}$ On the appearance of the general practitioner and the importance of competitive threat, see Irvine Loudon, Medical care and the general practitioner 1750-1850, Oxford, Clarendon Press, 1986. For a suggestive model of the importance of therapeutics as the basis of identification among practitioners see John Harley Warner, The therapeutic perspective. Knowledge and identity in America 1820-1885, Cambridge MA, Harvard University Press, 1986. For a specific study of a therapeutic controversy between orthodox and irregular practitioners see Roy Porter, " "I Think Ye Both Quacks": the controversy between Dr Theodor Myersbach and Dr John Coakley Lettsom', in W. F. Bynum and Roy Porter (editors), Medical fringe and medical orthodoxy, London, Croom Helm, 1987, pp. 56-78.

${ }^{57}$ On Beddoes's radicalism see Dorothy Stansfield, Thomas Beddoes M.D. 1760-1808: chemist, physician, democrat, Dordrecht, D. Reidel, 1984, especially chapters 6 and 7.

58 Brown, op. cit., note 1 above, p. cxxxvi.

59 On the ideologues see Erwin Ackerknecht, Medicine at the Paris Hospital 1794-1848, Baltimore, The Johns Hopkins Press, 1967; George Rosen, 'The philosophy of ideology and the emergence of modern medicine in France', Bull. Hist. Med., 1946, 20: 328-39. On Cabanis see Martin Staum, Cabanis. Enlightenment and medical philosophy in the French Revolution, Princeton University Press, 1980.

60 Brown, op. cit., note 1 above, p. clix. On Beddoes on education and medical policing see Stansfield, op. cit., note 57 above, pp. 197-215. On medical police in France see L. J. Jordanova, 'Policing public health in France 1780-1815', in Teizo Ogawa (editor), Public health, Tokyo, Saikon, 1981, pp. 12-21. The use of Brunonianism by the various members of Beddoes's Bristol circle, in particular the young Humphry Davy, who was later an explicit vitalist, would make an interesting study: see Michael Neve, 'The young Humphry Davy: or John Tonkin's lament', in Sophie Forgan (editor), Science and the sons of genius. Studies on Humphry Davy, London, Science Reviews, 1980, pp. 1-32.

${ }^{61}$ Brown, op. cit., note 1 above, p. cxlvii.
} 


\section{Christopher Lawrence}

Cullen had written, "It is probable that the nervous fluid in the brain, is truly capable of different states of excitement and collapse." To this, however, Beddoes added:

In his youth, this author had imagined a mechanical hypothesis respecting the nervous fluid, which he regarded with fondness through life, and unfolded with great prolixity in the decline of his powers. When he wrote the passage I have quoted, his thoughts were turned from the living body to an electrical machine; and he evidently does no more than describe the common experiment, in which a congeries of flexible fibres is made to stand erect, and to diverge by electricity, and then shrinks together on the application of a conducting substance. His idea of excitement has therefore nothing in common with that of Brown. ${ }^{62}$

On Beddoes's reading, Cullen was an old-fashioned Boerhaaveian mechanist. This was a position which Beddoes reinforced by the argument that, before Brown, "investigations relative to medicine, had been carried on just as rationally as if to discover the qualities of the horse, the naturalist were to direct his attention to the movements of a windmill." 63 Beddoes's distinction between the ideas of Cullen and those of Brown was part of Beddoes's radical reading of Brown's text. Cullen was being associated with the past, the establishment, orthodoxy and tradition, and Brown was being identified, not with reform, as in the Inquiry, but with revolution.

Other radical readings of Brown's texts would make an interesting study. In particular, it might be rewarding to examine the ways in which authors interpreted Brown's view on the nature and seats of life. In the works of Cullen and other Edinburgh professors, the nervous system was designated as the fundamental source of all bodily sensation and motion, and the system through which all activity was mediated. Muscles were not designated as possessing autonomous irritability, as in Haller's system; rather, any apparent autonomous movement they showed was caused by residual nervous power. This model, I have suggested, was the medical view which corresponded to the Lowland literati's account of themselves as the élite managers of Scottish life. ${ }^{64}$ Where Brown situated vitality was variously interpreted. In the Inquiry, Jones asserted that Brown's system "applies not only to animal but to vegetable life". 65 Democrats certainly interpreted Brown as having distributed vital power either throughout the body or at least as existing equally in the muscles and the nerves. ${ }^{65}$ Beddoes proclaimed that Brown taught "Excitability is seated in the medullary portion of the nerves, and in the muscles". ${ }^{66}$ Robert John Thornton, a Cambridge MD who had studied in Edinburgh, was probably another radical. By 1793 he was communicating the results of pneumatic experiments to Beddoes. ${ }^{67}$ In a work published in 1795, he interpreted Brown in much the same way as Beddoes had done. He was more generous about Cullen than Beddoes had been, but Brown he regarded as

62 Ibid., p. cxlvi.

63 Ibid., p. clxi.

64 Christopher Lawrence, 'The nervous system and society in the Scottish Enlightenment', in Barry Barnes and Steven Shapin (editors), Natural order: historical studies of scientific culture, Beverly Hills CA, Sage, 1979, pp. $19-40$.

65 Jones, op. cit., note 42 above, p. 87.

${ }^{66}$ Brown, op. cit., note 1 above, p. cxxviii.

${ }^{67}$ See Thomas Beddoes, Letters from Dr Withering of Birmingham, Dr Ewart of Bath, Dr Thornton of London and Dr Biggs, late of the Isle of Santa-Cruz, Bristol, Printed by Bulgin and Rosser, [n.d.]. Thornton's letter is dated 7 December 1793. See also William Munk, The roll of the Royal College of Physicians of London, 2nd ed., London, The College, 1828, vol. 3, p. 98. 


\section{Cullen, Brown and the poverty of essentialism}

"the father of the true science of medicine". ${ }^{68}$ In particular, he praised Beddoes for his recognition that Brown was the first to deal with the phenomena of life, eschewing "unmeaning and vague terms". ${ }^{69}$ Thornton wrote that Brown "attributed all the phenomena of life to the fibrous system, extending his doctrine to plants."70 Similarly, Erasmus Darwin, who described Brown's Elementa as "a work of great genius" wrote of "the spirit of animation residing in the contracting fibres".71

Other authors also regarded Brown's text as revolutionary. They did not, however, see it as original. In the years of the French Wars, Thomas Morrison, Member of the Royal College of Surgeons of England, produced his Examination into the principles of what is commonly called the Brunonian system. ${ }^{72}$ Morrison's text addressed both the Brunonian system, and the use which had been made of it by the physician and popular lecturer Thomas Garnett. ${ }^{73}$ There can be little doubt about the community from which Morrison drew his perceptions of Brunonianism. "Brown", he began, "in his general acceptation [sic] of the word excitability appears evidently to mean the vital and mental principle of life and mind ... [and] ... I shall therefore wish the words Excitability, Vital Principle or Life to be considered synonimous [sic]."74 But, he argued, Brown's description of the nature of the vital force was "confused, indistinct, and obscure". 75 Far from being a Newton of the living world, Brown had fundamentally misunderstood what a Newtonian explanation should look like. Life, the vital principle, said Morrison, was like gravity, ever constant and unchanging and the cause of vital actions. Brown, however, had designated life not only as a principle, but as the varying effect of stimuli on that principle. He had mistakenly identified the vital actions produced by the living principle with life itself. The cause of this error, said Morrison, lay in Brown's failure to recognize the importance of organization in living things. According to Morrison, Brown taught that stimuli acted directly on the vital principle and their action had no dependence on organization. But, said Morrison, "the very reverse of all this is the case; for it is only through the organization of the body that life exerts its powers."76 Not surprisingly then, Morrison added, because

\footnotetext{
68 'A Friend to Improvements' [Robert John Thornton], The philosophy of medicine, 4th ed., London, C. Whittingham, 1799, vol. 1, p. 128.

69 Ibid., p. 255.

70 Ibid., p. 122.

${ }^{71}$ Erasmus Darwin, Zoonomia; or the laws of organic life, London, J. Johnson, 1794, vol. 1, pp. 74-5. Darwin's account of the relationship of the nerves to muscular motion is not easy to explicate and seems open to a number of readings; see ibid., pp. 7-11. Darwin certainly taught that plants had vital properties. For a very particular reading of Darwin see Maureen McNeil, Under the banner of science: Erasmus Darwin and his age, Manchester University Press, 1987, pp. 148-67.

72 Thomas Morrison, An examination into the principles of what is commonly called the Brunonian System, London, Highley, [1806]. I have been unable to discover for certain who Morrison was. The title page designates him as "MRCS". There was a Surgeon-Apothecary Thomas Morrison who retired from the army in 1783: A. Peterkin and William Johnston, Commissioned Officers in the medical services of the British Army 1660-1898, London, The Wellcome Historical Medicine Library, 1968, entry 842.

${ }^{73}$ See T. Garnett MD, A lecture on the preservation of health, Liverpool, printed by J. M'creery, 1797. Garnett, a radical, had used the concept of excitability to present a view of life similar to that described by Beddoes. Since he did not actually produce an interpretation of the Brunonian system I have not dealt with him here. On this intriguing figure and for a bibliography see S. G. E. Lythe, Thomas Garnett (1766-1802), Highland tourist, scientist and medical professor, Glasgow, Polpress, 1984.

74 Morrison, op. cit., note 72 above, pp. 14-15.

75 Ibid., p. 26.

${ }^{76}$ Ibid., p. 42.
} 


\section{Christopher Lawrence}

Brown was not interested in organization, "To the Brunonian System the knowledge of anatomy can be of no use ...".77 Indeed, he scoffed, Brunonians will soon assert "the labours of anatomists are of very trifling moment."78 Further, Brown, by his neglect of organization and his failure to understand the nature of the living principle, had fallen into the error of materialism, or, as Morrison put it: "His apprehension of being suspected of having material notions of life, seems to have proceeded from his really having such."79

There were, Morrison added, further difficulties with the system: "The laws of the animal economy are uniform and equal in all their effects, what is the strength of one power can never be the weakness of another."80 Thus, he noted, the Brunonians foolishly explained the painful reaction of the eye kept in darkness and then exposed to the stimulus of bright light by postulating an accumulation of excitability. ${ }^{81}$ But, Morrison argued, Brown had described an impossible situation: a small stimulus producing a great effect. The real reason for the response lay in the protective action of the eye muscles. Because of the design of the body, danger to the eye, indicated by pain, evokes the appropriate response. In his catalogue of Brown's errors, Morrison held that he had variously seated excitability, or the vital principle, in the nervous substance and muscles, or throughout the body's fibres. In either case the radical possibilities seemed clear to Morrison, who noted that Brown's view overlooked "The circulatory system . . . [which] . . . will be found to be perhaps more necessary to the action of excitability than the nervous." 82

In the light of Morrison's explication of Brunonianism it is possible to offer a conjecture about the origin of his views. He was probably a London surgeon, and almost certainly a direct or distant disciple of John Hunter. Within the Hunterian school, the starting points of anatomical and physiological investigation were the existence of an autonomous and unknowable vital principle, the centrality of organization, and the importance of the blood and the vascular network. The methods of investigation were anatomical dissection and experiment; and the aims were, as Morrison put it, to trace "effects discernible in nature . . to their great First Cause". 83 For Morrison, therefore, Brunonianism represented the very antithesis of all these things: it negated the importance of anatomy, it was materialist, irreligious, and thus potentially productive of the very worst social consequences. As he put it,

The general conclusions of the Brunonian system lead to the most gross and false ideas of the nature of life and mind. The magnitude of this last objection, both in a physical and a moral point of view, is deserving of particular attention. The deplorable consequences which have arisen to society from the propagation of opinions connected with such erroneous notions, more especially in a neighbouring country, is too fresh in the minds of everyone to require repetition. $^{84}$

${ }^{77}$ Ibid., p. 96.

78 Ibid., p. 104.

79 Ibid., p. 35.

80 Ibid., p. 72.

81 The example is used by Garnett, op. cit., note 73 above, p. 14.

82 Morrison, op. cit., note 72 above, p. 21.

83 Ibid., p. 131 .

84 Ibid., p. 126. On the revolutionary meanings of physiological texts in this period see Owsei Temkin, 'Basic science, medicine and the Romantic era', Bull. Hist. Med., 1963, 37: 97-129. 


\section{Cullen, Brown and the poverty of essentialism}

To a devout, presumably Tory, London surgeon, there was nothing new in Brunonianism. Here was something familiar and very nasty: French materialism, irreligion and Jacobinism dressed up in "crude notions", arrived at by either a simple misunderstanding of the nature of life or devised with some more sinister intent.

For James Jackson senior, a Boston physician, writing on the Brunonian system in 1809 , its essential features seemed to be of a rather different sort. In the early nineteenth century, educated Boston physicians saw themselves as the source of light in a country of medical darkness. Hostile to systematizing of all kinds, they portrayed themselves as the custodians of cautious, empirical, and sceptical medicine. They identified medical progress with the clinics of London and Paris, and with the gradual accumulation of knowledge by means of the bedside description of disease and the labours of the post-mortem room. ${ }^{85}$ Thus on the very first page of his account of Brunonianism, Jackson wrote that, at a time "when the wisest physicans had already entered the path of truth, that of observation, experience and induction; the path which Hippocrates and Sydenham had trod with so much success; and at a period when all were desirous to follow in this path ... Brown ... declared, that by the discovery of one principle he was able to explain all the secrets of physiology and medicine." In so doing, he "imitated all theorists in distorting all the other phenomena of nature". ${ }^{86}$ Jackson saw as the essence of Brunonianism its methodological prescriptions which contained an idea "directly in opposition" to "the science of medicine". 87 "According to Brown," Jackson wrote, "it is useless to record the phenomena of disease, to collate and compare cases; for these phenomena, these symptoms, are fallacious." 88 All this, he wrote, was contrary to "the plan of observation and experience . . by which some men in all ages have been qualified to render more or less service to the sick, in spite of the various systems which the fashions of various ages have rendered popular."89

Thus a single medical principle was both the keystone and the fundamental flaw in Brunonianism. Excitability was nothing more than a speculative hypothesis, "the properties [of living things] . . . are discoverable only by observation and experiment."90 The dangers of Brunonianism were all too obvious: it was simple, whereas experience taught that medicine was complex. It indulged indolence and discouraged medical men "from poring over the observations of others".91 Systematizing had led Brown to egregious errors. It was possible to conclude from Brown's system that "there cannot be any such thing as a strictly local disease." This, Jackson said, was "stargazing".92 Jackson, a man trained in London and Paris hospital medicine, was, of course, highly sympathetic to the idea that all diseases were local.

It is hardly surprising to find such a reading of Brown in this Boston physician. For him, the essence of Brunonianism was its method, the erection of a system of medicine on philosophical principles. Here, at least, Jackson was in agreement with the author of

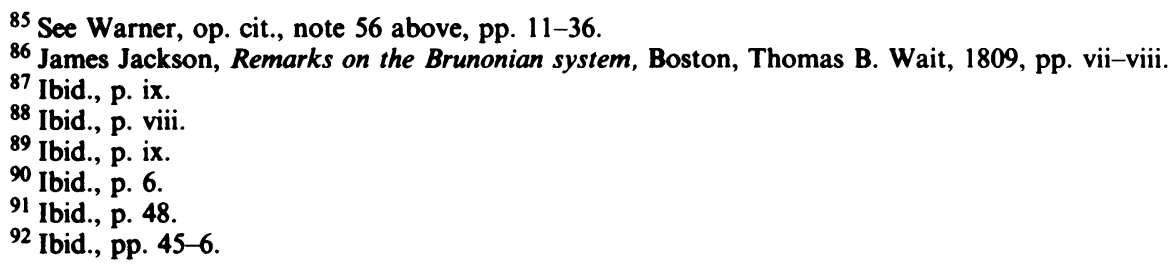




\section{Christopher Lawrence}

the Inquiry. But if for Brown this was a triumph, for Jackson it was a disaster. Systems of any sort denied the value of experience and learning, and appealed only to the simplifiers and the simple. To embattled Boston physicians, aristocrats of the American medical world, who had staked their claim on scepticism, nosography, post-mortem and tradition, Brunonianism posed the threat of democracy and equality among medical practitioners. It was the sort of medicine that gave legitimacy to quacks, herbalists, homeopaths, Perkinistic practitioners, electricians, Mesmerists and the whole tribe of toadstool millionaires. ${ }^{93}$

If Thomas Beddoes had seen Brown's system as essentially different from Cullen's, John Thomson saw it as essentially the same, a downright plagiarism in fact. Thomson was an Edinburgh-trained surgeon who had been a student when Cullen was an old man. Later, when Thomson became an extramural teacher of surgery in Edinburgh, he was committed to the view that surgery and physic were the practical faces of one basic discipline, pathology. It was a position which he defended in numerous publications. His biography of Cullen and his edition of Cullen's works were also enterprises devoted to demonstrating this. ${ }^{94}$ The élitism of physicians, which was how Thomson represented Brunonianism, was anathema to him. In situating Brown and Cullen, Thomson reconciled apparently opposite propositions. On the one hand, he represented Brown's system as that of a simpleton, and Cullen's work as that of a profound and original thinker; and, on the other, he portrayed Brown as having stolen the principles of his system from Cullen. In his account of Brunonianism Thomson also discussed Beddoes's interpretation of Cullen.

There was nothing new in Brown's thinking, Thomson protested. The appeal of his opinions lay only in the "novelty of the terms ... the simplicity of the views ... and the ease with which a knowledge of these could be attained". 95 Unlike the radical Beddoes, but like the Tory Morrison, Thomson took the view that Brown had "attributed the phenomena of the animal economy to the agency of a single unknown principle". 96 Moreover, also like Morrison, he argued that Brown was not the first to do so. Brown's excitability, he said, "comprehends nothing more than what had been expressed by preceding physiologists and pathologists under the various appellations of Soul, Sentient Faculty, Archeus, Vitality or Vital Principle, and Animal Power, or Energy of the Brain." 97 Cullen himself, Thomson added, had used the terms "Excitability", "Exciting Powers", and "Excitement". Thomson then addressed Beddoes's mechanistic reading of Cullen, and cited Cullen to the following effect: "We suppose", said Cullen, animal "life, so far as it is corporeal, to consist in the excitement of the nervous system". 98 This, said Thomson, was not a simple mechanist statement of the Boerhaaveian sort, as Beddoes suggested, but a new idea of vitality, of which Brown had presented a derivative version. Similarly, Thomson claimed, the opinion that life was a forced state was one that "Dr Brown must have had repeated opportunities of

\footnotetext{
93 James Harvey Young, The toadstool millionaires, Princeton University Press, 1961.

94 I have discussed the social and intellectual context of Thomson's views in Christopher Lawrence, 'The Edinburgh Medical School and the end of the "Old Thing" ', Hist. Universities, 1988, 7: 259-86.

95 Thomson, op. cit., note 15 above, p. 224.

96 Ibid., p. 228.

97 Ibid., p. 229

98 Ibid., p. 230.
} 


\section{Cullen, Brown and the poverty of essentialism}

hearing" from Cullen. ${ }^{99}$ In addition, Thomson claimed, this view could be found in Cullen's printed Materia medica. This, said Thomson, was the meaning of the following sentence from Cullen:

That the soul is constantly necessary to the motion of the body we readily admit, but the argument is pushed too far, when it is supposed that these motions are supported by the power of the soul alone; for it appears that motions, excited by the impulse of external bodies, are absolutely necessary to that support. ${ }^{100}$

"In . . considering the nervous system as the seat of his excitability", Thomson continued, "Dr Brown's opinions ... were derived from, or modelled upon, those of his preceptor." 101 This, Thomson averred, was the import of Cullen's sentence, "The power of excitement ... distinguishes the vital solid ... but the brain, as uniting the whole nervous system has peculiar functions upon which the rest is dependent."102 However, although Thomson represented Brown as having taken the idea of a single vital principle in the nervous system from Cullen, Thomson was equally concerned to show that Cullen, unlike Brown, really believed in three vital powers. Cullen, Thomson wrote, was "at great pains to distinguish between the sentient power or irritability of the nervous fibres, - the moving power ... of the muscular fibres,- and the animal or innervatory power or energy of the brain." 103 Only once, said Thomson, did Cullen "somewhat unguardedly" comprehend the three powers under one common term. ${ }^{104}$ It was this unguarded moment which was the source of Brown's idea of a single vital power: excitability.

Why was Thomson at such pains to represent Cullen as having really posited three vital principles, which Brown stole and conflated into one? Brown, said Thomson, by using only one principle could draw the conclusion that "sense, motion, the mental functions, and the passions, . . . are all produced . . . by mechanical impulse."105 Thomson, in other words, accused Brown of using only one principle since he believed mental and corporeal functions to be identical. He was, in other words, a materialist. It was for this reason that Thomson represented Cullen as the teacher of three vital principles, one of which was the origin of mental operations. Thomson, the Whig, member of the Edinburgh establishment, former pupil and friend of Dugald Stewart, was imputing stout religious orthodoxy to the Edinburgh professoriate. Thomson's biography contains no suggestion that Cullen was a materialist. Accusations of this sort, however, had been bandied about in earlier years. ${ }^{106}$ What Thomson saw as central to Brown's system was the abuse of an unguarded remark by a great professor.

In a later passage, Thomson performed an almost identical piece of surgery on the texts. Once again he identified Brown as a materialist, excused Cullen from such an

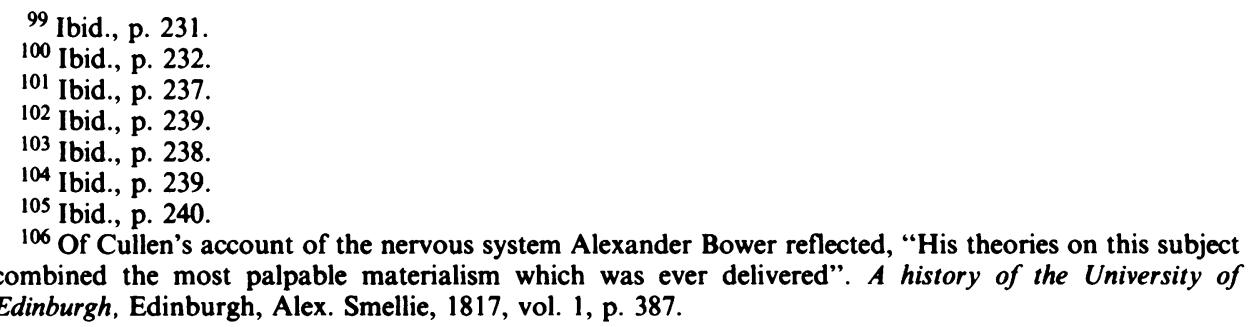




\section{Christopher Lawrence}

accusation, and simultaneously pointed to plagiarism on Brown's part. Brown's view, said Thomson, quoting him, was that all stimuli act by "evident impulse". ${ }^{107}$ Thomson argued that Brown had pilfered the idea from Cullen, who, in another unguarded moment no doubt, "seems to have taken [it] incautiously from Mr Locke."108 Brown stole the idea from the following passage of Cullen's: "we know" wrote Cullen "of no other action of bodies on each other but that of impulse." 109 Such a passage, however, being open to misconstruction as materialist, Thomson added that Dr Cullen "seems to have been aware that the supposition of the phenomena of living systems, being produced by the operation of impulse alone, is founded upon a partial consideration of these phenomena." 110 Thomson then quoted the appropriate passage to prove that Cullen really did not believe "an hypothesis which ... [explains] all the actions produced in the animal economy by mechanical impulse." 111

And so Thomson went on, demonstrating Brown's plagiarism by juxtaposing passages from his works with passages from Cullen which meant, Thomson said, exactly the same thing. For instance, Brown's assertion that "Predisposition to disease is a middle state of Excitement between perfect health and disease", was, Thomson averred, identical to Cullen's view "that health may deviate, on either side, from the standard without passing to the opposite state, that of disease."112 Similarly, Brown's distinction between direct debility and indirect debility was recognized by Cullen in his account of "repeated excitement ... . wearing out the system", and his statement that "such is the constitution of the nervous system that every unusual degree of excitement is followed by a proportional degree of collapse."113 There remained for Brown, said Thomson, "only the merit of having applied the term[s]". 114

There was, however, one area in which Thomson represented Brown's system as quite unlike that of Cullen's. Brown, according to Thomson, supposed that all the "morbid conditions of the different organs and functions" could be reduced to "two opposite conditions of the animal economy". 115 Cullen by contrast, Thomson said, had taught a complex pathological doctrine based on the concept of a variety of possible proximate causes. The reasons for Thomson's reading of the texts in this fashion relate to his occupation as a surgeon and his interest in general pathology. By the early nineteenth century, the surgeons in Edinburgh had eroded much of the power of the physicians, and in doing so they had gained entry into the traditional areas of practice claimed by them. This collapse of the old order was both institutional and intellectual. Thomson, in his Lectures on inflammation of 1813, claimed that distinctions between medicine and surgery were spurious, since the distinction between their objects of study - external and internal diseases or local and general disorderswas based on a misunderstanding of disease processes, a fact made clear by clinical

\footnotetext{
107 Thomson, op. cit., note 15 above, pp. 245-6.

108 Ibid., p. 247.

109 Ibid.

110 Ibid.

111 Ibid.

112 Ibid., p. 253.

113 Ibid., p. 255.

114 Ibid., p. 256.

115 Ibid., p. 259.
} 


\section{Cullen, Brown and the poverty of essentialism}

medicine and general pathology. ${ }^{116}$ Pathology for Thomson was the fundamental medical science, based, as he conceived it, on experiment and post-mortem. It was a complex, hard and learned discipline, which underlay both medicine and surgery. It was a science which Thomson identified with Cullen's injunction to discover proximate causes. ${ }^{117}$ Thus Thomson represented the Brunonian system as embodying everything that proper pathological science was not. Brunonianism was facile, easily apprehended, taught that there were only two pathological states, trivialized the importance of local disease, misunderstood the role of nosology and minimized the need for surgery by an insistence on the general nature of all disorders.

According to Thomson, the Brunonian practitioner had only a few simple decisions to make, the first being to decide whether disease was local or general. This was a distinction Thomson found entirely spurious: "how little foundation", he wrote, "there exists in nature for making so strict a division of diseases." 118 Thomson further noted that, although Cullen's nosology contained the classes of local and general diseases, Cullen "seems to have been at all times fully aware how often these two kinds of disease coexist."119 This was, of course, a pathological doctrine central to Thomson's bid to unite medicine and surgery. Local and general disease were the objects of study of the same discipline, pathology, and the focus of clinical attention for physician and surgeon alike. But it was Brown's view, he said, quoting him, that local and general disease "differ in every essential respect". ${ }^{120}$ Thomson's reading of Brown as hostile to the concept of local disease went further than this, however. According to Thomson, Brown had removed a whole class of local diseases, the inflammations, from the provenance of the surgeon, and stated they were a consequence of general dysfunction and thus properly within the sphere of the physician. Thomson then noted that perusal of Cullen's First lines would "leave but little doubt as to the source from which Dr Brown's opinion ... had been derived". ${ }^{121}$ This, however, was a reading of Brown similar to the one which imputed materialism to him. On the one hand, Thomson showed that Brown's views were mischievously derived from Cullen; and then he demonstrated that Cullen, like himself, actually held a rather different opinion. In this case, Thomson suggested that Cullen provided a far more sophisticated account of the relation of local to general disease which did not, in fact, privilege general disease over local.

Thomson then went on to give an account of the Brunonian practitioner's role after he had decided that a disease was a general disturbance. According to Thomson, the Brunonian practitioner had then only to discover whether the disorder was one of vigour or debility. Once again, Thomson attempted to rob Brown of invention by remarking that the two states "had been fully recognised and described [by Cullen] under the various terms of Increased and Diminished Action, Excitement and

\footnotetext{
116 John Thomson, Lectures on inflammation, Edinburgh, William Blackwood, 1813. For a discussion of the breakdown of the boundaries between physic and surgery in Edinburgh and a guide to the literature see Lawrence, op. cit., note 94 above.

117 Thomson, op. cit., note 15 above, p. 259.

118 Ibid., p. 300.

119 Ibid.

120 Ibid.

121 Ibid., p. 303.
} 


\section{Christopher Lawrence}

Collapse, Reaction and Debility." 122 Brown, however, had gone too far and attempted "to refer all diseases to one or other of these two states, and to reduce the whole of medical practice to two general plans of treatment". 123

Beddoes, in his estimate of Brown's work, had endorsed Brown's view that much of his originality lay in his recognition that reasoning to causes because of nosological similarity was fallacious. According to Brown, nosology was a misguided enterprise since two diseases, juxtaposed on a nosological table, might in fact originate in fundamentally different states of excitement. Thomson, however, identified this so-called insight of Brown's as a part of a fundamental failure to understand the aim of nosology. Thomson, who obviously thought that Brown had taken leave of his senses, wrote, "In his recommendation to physicians to judge of the . . . character of diseases by the nature of the exciting powers which produce or remove them, and not by the symptoms they exhibit ..., Dr Brown seems to have lost sight altogether of the . . . principle ... that all that can be known of [these exciting powers] . . must be derived from the observation of the sensible effects": ${ }^{124}$ in other words, the symptoms. Brown had thus completely confused symptomology, which is the art of judging vigour and debility by particular symptoms, with nosology, the expression in accurate characters of "the order which nature general observes . . . the concourse or succession of symptoms". 125 So risible, indeed, was Brown's reasoning, argued Thomson, that he had had to make use of nosology whether he liked it or not. Not surprisingly, Thomson continued, the nosology Brown implicity used was Cullen's. The putative vanquishing of nosology achieved by Brown and applauded by Beddoes produced a hostile response from Thomson, a surgeon and pathologist sympathetic to the new approach of grounding natural histories in morbid anatomy.

For Thomson, Brown's speculations "had their origin in personal spite, arising out of wounded vanity". In turn "the malignant and rancorous animosity displayed in the writings . . . take away the pleasure which might have been derived from the manifestation of such talent as he had evinced." 126 For Thomson, Brown's system was derived in its essentials from Cullen or, as in the case of the use of stimulants, "in a desire to contradict precepts inculcated by $\mathrm{Dr}$ Cullen in his lectures and writings". ${ }^{127}$ All else was dross, jargon and neologisms, or worthless and dangerous prescription. It was a materialist system, void of surgical or pathological value. Thomson's perceptions of the proper nature of the theory and practice of medicine, with all that they entailed for the ordering of society, were those which were valued by the Edinburgh establishment. In 1831 he was made the first professor of pathology in the University.

Thomson, however, did not dispose of Brunonianism for good. In the nineteenth century a number of authors came to Brown's defence. One of these was the English physician, Benjamin Ward Richardson, whose biographical history of medicine,

122 Ibid., p. 306.
123 Ibid.
124 Ibid., p. 308.
125 Ibid.
126 Ibid., p. 351.
127 Ibid., p. 324. 


\title{
Cullen, Brown and the poverty of essentialism
}

Disciples of Aesclepius, included a short account of him. Richardson wrote: "In this purely mechanical day, when nothing is allowed that is not experimentally illustrated, the hypothesis of Brown may seem, and, I doubt not, does seem, a mere fancy." 128 Yet, for Richardson, there was something in Brown's work that showed its author "was a man gifted with curious insight, a man of genius of a very high order". ${ }^{129}$ This genius lay in Brown's "abstract reading of vital phenomena". ${ }^{130}$ For Morrison and Thomson, Brown had been a materialist and had utterly misconstrued the problem of life. For Richardson the reverse was the case. He wrote "To this day we have not come much nearer to the solution of the great question of life than the hypothetical solution which he [Brown] advanced."131 For, said Richardson,

\begin{abstract}
his conception that every living thing is pervaded with some inherent quality or substance which is its natural portion, its allotted portion, and upon the stock of which its capability for life, long or short, depends, is as sound a view as has ever been advanced and explains more of the phenomena of life than any other. ${ }^{132}$
\end{abstract}

This, said Richardson, is what John Hunter called the vital principle. Richardson was himself a vitalist. "We may have to admit", he wrote, "that there is a quality or substance ... which whether it be from the first allotted, or whether it be regularly replenished, endows every living thing with life." 133 Why then did Richardson construe Brown as holding the same view as himself rather than portray him as a materialist, as had more often been the case?

Richardson was in many respects the archetypal cultured Victorian doctor. From a relatively humble beginning he achieved great success. He was a gentleman (knighted indeed), broadly learned and a lover of history and the classics. He was also a devout man in an age in which the biological sciences, which for him evidenced the existence of a Deity, were-in T. H. Huxley's evolutionism or Michael Foster's experimental physiology - threatening a new materialism. Richardson's vitalism was part of his theology. Richardson believed in a supreme being, and held medicine to be one of the oldest and most humane arts, devoted to the relief of suffering. In reading Brown as a vitalist, he was creating a single, ageless medical profession and attributing to it Victorian conceptions of humanity and piety. For him the greatest profession could not be, since its historical beginning, anything other than learned and pious. As he put it in another context, "No medical man can be a materialist."134 John Brown testified to that. With Richardson the cycle had come almost full circle. Brown the reformer, then the revolutionary, had become a conservative.

In other contexts, however, other readings remained possible. In America Brunonianism could still be made to stand, symbolically, as a threat. Competition from sectarians remained vigorous in American medicine well into the twentieth

128 Richardson, op. cit., note 2 above, p. 253.

129 Ibid.

130 Ibid.

131 Ibid.

132 Ibid.

133 Ibid., p. 254.

134 Quoted in Sir Arthur Salusbury MacNalty, A biography of Sir Benjamin Ward Richardson, London, Harvey Blythe, 1950, p. 76. 


\section{Christopher Lawrence}

century. By this time, however, the ideological defence of orthodoxy on the basis of observation and experience, employed by Jackson, had shifted to an appeal to the experimental and laboratory sciences as the agencies which conferred on the profession its right to be the legitimate guardian of the public's medical welfare. ${ }^{135}$ In 1911 , Richard Cole Newton MD published an address he had given to the Orange Mountain Medical Society on Brown and the Brunonian system. Newton quoted extensively from Richardson's account of Brown's work and summed up the significance of Brunonianism as follows:

That a rational man should not only have attempted to build up, but actually did build up a theory of the etiology of all human diseases and their treatment upon such facts, which no one disputes, as that alcohol and opium, if taken in sufficient quantities, will allay pain and stimulate the imagination, would be quite incredible did not every student of the history of medicine know that the various systems and sects in the practice of medicine have been built up and defended on even more ephemeral grounds than these. ${ }^{136}$

The significance of Brunonianism lay not in its detail, but in the fact that it was a system built, like all systems, on random, uncontrolled, unscientific observation. Because it was a system, it assumed, said Newton, that "the physician not nature cures the disease." 137 Such theories and systems, he said, "form a refuge for the unlearned and narrow medical mind." 138 Further, they "can fool the laity and even arouse the wild enthusiasm of the prejudicial and unthinking practitioner." 139 But such "fiat medicine" was not "real medicine". ${ }^{140}$ Sadly, he noted, some of Brown's ideas "are still exceedingly potent in the minds not only of the laity, but of the profession." 141 One of these "errors" was (and here Newton agreed with Richardson's reading but disagreed with the endorsement) that a "vital principle, vital energy or strength" is assigned to every being. ${ }^{142}$ Such vitalism was nonsense, "a fundamental and foolish error which is one of the main props of fiat medicine". ${ }^{143}$ Progress in medical science, however, was exposing such things for what they were. For instance
the consumption of alcoholic beverages, the sheet-anchor of his system, has been steadily decreasing since Brown's day, and this decrease has been notable during the past few years, largely because the white light of science has been turned upon the study of the effects of alcohol upon the human body. ${ }^{144}$

Everywhere, Newton observed, systems, or "fiat medicine", were falling prey to "scientific investigation". ${ }^{145} \mathrm{He}$ concluded:

\footnotetext{
135 See Warner, op. cit., note 56 above.

136 Richard Cole Newton, 'John Brown M.D. and the Brunonian system of medicine', Medical Record, 2 December 1911, pp. 1-23.

137 Ibid., p. 20.

138 Ibid., p. 22.

139 Ibid., p. 23.

140 Ibid.

141 Ibid., p. 18.

142 Ibid., p. 19.

143 Ibid., p. 20.

144 Ibid., p. 18.

145 Ibid., p. 19.
} 


\title{
Cullen, Brown and the poverty of essentialism
}

\begin{abstract}
We still have doctrines and systems and hypothetical explanations of natural phenomena, but the white light of science has grown too strong for us. The medicine of the future will, we believe, not be, like that of the past, largely controlled by dogma, superstition and tradition. It will be scientific medicine and the true physician of the future will not be ashamed to say that he does not know a thing that science has not yet made clear to him, and will not condemn an innovation simply because it does not conform to his theories, and because he cannot measure it with his yardstick. ${ }^{146}$
\end{abstract}

Newton's account is the one that might be expected from a learned American MD at this time. The essence of Brunonianism was its systematic construction; it was read by this American physician as an object lesson on the evils of populism and the necessity of making experimental science the cornerstone of practice.

My intention in presenting these differing accounts of Brown's career and the career of his writings should now be sufficiently plain. Scrutiny of previous readings of Brown's texts reveals that authors could not agree on their essential meanings; or, put another way, different readers have discerned different essential meanings according to their situation. Even excitability, apparently a key feature of the system, was represented differently by Beddoes and Morrison. Recently historians have begun to turn their attention to these sorts of questions, to study, for example, not the works and influence of some essential John Hunter, but a number of rather different John Hunters made for a specific purpose by subsequent generations, and in turn handed on to us as an apparently uncomplicated object, the father of scientific surgery. ${ }^{147}$ Similarly, historians have now found that there was not one Newton in the eighteenth century, but many. ${ }^{148}$ The discovery that, from day one, Brown's texts were the subject of interpretation does not mean that the modern historian can now return to them and gain privileged access to some putative essential meaning; quite the reverse. It should free the historian from the constraint of having to discover the meanings Brown's texts have for us, and lead to an understanding of the place of Brown and his work in the eighteenth and nineteenth centuries.

\footnotetext{
146 Ibid., p. 23.

${ }^{147}$ See L. S. Jacyna, 'Images of John Hunter in the nineteenth century', Hist. Sci., 1983, 21: 85-108. See also P. B. Wood, 'The hagiography of common sense: Dugald Stewart's account of life and writings of Thomas Reid', in A. J. Holland (editor), Philosophy, its history and historiography, Dordrecht, D. Reidel, 1983, pp. 305-22. See Wood's first footnote for similar material dealing with French doctors and natural philosophers. See also J. R. R. Christie, 'Joseph Black and John Robison', in A. D. C. Simpson (editor), Joseph Black 1728-1799. A commemorative symposium, Edinburgh, The Royal Scottish Museum, 1982 , p. $47-52$.

${ }_{148}$ Simon Schaffer, 'Natural philosophy', in G. S. Rousseau and Roy Porter (editors), The ferment of knowledge, Cambridge University Press, 1980, pp. 55-92.
} 